\title{
Ecological Assessment by Physical Chemical and Biological Interactions Analysis in Trophic State of Libelula's Wetland - Bogotá - Colombia
}

\author{
Liliana Ardila, Steven Mora, and Ruth Flórez
}

\begin{abstract}
Due to the serious problems that affect aquatic ecosystems around the world, human survival has been put in risk. _Colombia has been considered to have a great hydric wealth but its people are suffering of water supply limitation and the reception of less quality water due to inappropriate use of water resources. For this reason, many actions have been taken to keep in observation lotic and lentic water body's performance, taking in count all nature and human contributions which may disrupt to greater of lesser degree the water quality and viability of aquatic species. Therefore, this permanent inspection has helped in the proposal of solutions to avoid or alleviate the harm done in water bodies and recover them to guarantee the typical functioning of hydric ecosystem.

With this point of view, it was proposed an ecological assessment of an urban wetland called "Libelula", injured by neighboring community. In this project, the Carlson's Trophic State Index was employed and the inspection of the relationships between living species and physicochemical parameters by the application of PCA methodology was also done. Results show that eutrophic state has been reached generating an increase of certain phytoplankton, zooplankton and macrophytes species, which have been associated with nutrient and organic matter enriched water ecosystems. The change of bathymetry of Libelula's Wetland in time was studied with GIS and UAV techniques showing a great negative impact principally because of residential activities which lead to lose important ecosystem services.
\end{abstract}

Index Terms-Ecological assessment, trophic state index, water quality, wetlands, limnology.

\section{INTRODUCTION}

Wetlands are hydric ecosystems, mostly of lentic behavior and depths less than six meters. Those present plenty of ecological, social and economic profits due to ecosystem's services they offer with highly ecological value [1,] [2].

According to Ramsar Convention, ecological value for wetlands, expresses the ecological importance of ecosystems by the relationships between their components which may be understood by economic value assignment and the identification of temporal changes. The Convention identifies five criteria for ecological assessment of wetlands which led authorities to establish the state of those ecosystems and

Manuscript sent February 24, 2018; revised July 15, 2018. This work was supported in part by ECCI University and Local Wetland's committee of Tunjuelito - Bogotá, Colombia.

Liliana Ardila is with Liliana Ardila Forero, Colombia (e-mail: lardilaf@ecci.edu.co, lardilaf@unal.edu.co).

Steven Mora is with Steven Ricardo Mora, Colombia (e-mail: stevenr.morag@ecci.edu.co).

Ruth Flórez is with Ruth Patricia Flórez Vargas, Colombia (e-mail: rflorezv@ecci.edu.co). assign an economic value. Mentioned criteria are naturalness and integrity, Diversity, Singularity or rarity, resilience and resistance, and capacity for renewal or recovery [1]-[3].

In this way, many efforts have been done to study wetland's behavior to preserve wetlands and many worldwide campaigns have been proposed to achieve rational spend of hydric resources. Despite those conservation actions, the extension and quality of wetlands are still in detriment as Davidson exposed. A Ramsar Convention Report of 2015 year, mentioned that the extension of wetlands in the world have decreased between 64 and $87 \%$ in the 20th century while the loss and degradation of them, continues at a relative rate of $2.5 \%$ (ha / year) [1], [4], [5].

Colombia is not out of touch of this problem and the most important difficulty to apply Ramsar Convention advices, is the lack of knowledge about the ecological value of wetlands. Therefore, those are often undervalued in assessments and decision-making process. A clear example takes place in Colombian big cities like Bogotá D.C, where degradation of wetlands has accelerated in the last 70 years. It was known that in 1950 the area of wetlands amounted to 50,000 hectares and nowadays is no more than 800 hectares [6]. In the city there are 34 wetland areas and only 15 are declared as District Wetland's Ecological Parks (DWEP or PEDH in Spanish) [7], [8] which should be cared for, according to national laws but their damage shows authorities' negligence.

A PEDH inside Bogotá city is the Tunjo Wetland's Complex. This ecosystem has been negatively impacted by direct and indirect human contributions over time [9]. Its continued degradation has allowed the loss of essential services that contributed to the well-being of nearby communities exposing them to consequences of environmental phenomena like climate change, floods, bad smell, proliferation of insects and rats, etc. [6], [10], [11].

In order to evaluate the above situations and give a partial guide who may help in taking decisions toward the recovery and preservation of the water ecosystem, this document presents the research done on one wetland of the Tunjo's wetland complex, called Libelula, to see possible relationships between physicochemical and biological point of view. Additionally with this study, it is wanted to obtain relevant information which could serve in ecosystem resilience models according to the criteria mentioned by Cumming in 2015 [12].

\section{MAtERIALS AND METHODOLOGY}

\section{A. Sampling Frequency}

The temporal variability of the phytoplankton and 
zooplankton responds to the patterns of variation of the illumination, turbulence of the water, temperature, $\mathrm{pH}$, and concentration of nutrients throughout the year. According to Roldan and Ramírez [13], the monthly monitoring allows to reach a level of description quite adequate, although the correct frequency would be biweekly. For this reason, sampling was carried out with periodicity no greater than 15 days during the first period of 2017.

\section{B. Physicochemical Parameters Sampling and Analysis Methods}

The physicochemical parameters which were chosen to study are: In situ parameters like temperature, $\mathrm{pH}$, conductivity, dissolved oxygen and turbidity with HANNA multi parametric measurement probe. Ex situ parameters like concentration of phosphates, ammonia, nitrites, Iron +3 and chemical oxygen demand COD were determined in the Genesys 2,0 spectrophotometer and chromium concentration were determined by atomic adsorption spectrometry AAS. Last parameter was evaluated because Tunjuelito River is crossing nearby Tunjo's Wetland Complex. This river had been affected by the wastewater of tanneries activities and it was desired to stablish the possible connection between those water bodies as a Libelula's wetland trophic state response. Each physicochemical analysis were done following the twentieth Standard Methods of water and wastewater [14]

\section{Limnologic Parameters Sampling and Analysis Methods}

Phytoplankton species were obtained by Wisconsin dragging net and quantification was done with the help of five milliliter Utermöhl Settling Chamber to separate biological species from water within a time of 24 hours without light and then an inverted lens microscope let the view and count of organism. Edward, Belinger and Utermöhl techniques were employed [15], [16]. Zooplancton species were obtained by throwing a net with a nozzle radius of $0.5 \mathrm{~m}$ and a length of $1 \mathrm{~m}$ and preserved in Bengal Rose at $4{ }^{\circ} \mathrm{C}$. The quantitative analysis of zooplankton consisted in performing a partial count through the systematic method of horizontal bands.

\section{Trophic State Determination}

Many trophic models have been proposed for limnologic research but Trophic State Index of Carlson also called T.S.I. index [13], is applicable to predict the trophic state of tropical water bodies. This model was calculated by the knowledge of parameters like clearness, and concentration of total phosphorous and chlorophyll - a. Clearness was estimated with Secchi Disk by the registration of the depth where instrument could not visible. Chlorophyll-a and other vegetal pigments like pheophytin were estimated by filtration of Libelula's wetland samples and subsequently extraction with acetone solvent and washes with $\mathrm{HCl}$. Pigments concentration was measured by Genesys 2,0 spectrophotometer between 665 and $750 \mathrm{~nm}$ of wave length to correct turbidity effects in the extract [17], [18]. The calculation of chlorophyll-a is:

$[$ Pheophytin $-a]=($ Abs @ $665 \mathrm{~nm}-$ Abs @ $750 \mathrm{~nm}) * F * K$

Equation 1

$$
[\text { Chlorophyll }-a]=[\text { pheophytin }-a] * \frac{v}{V}
$$

Equation 2

where [pheophytin -a] and [Chlorophyll -a] are pheophytina and Chlorophyll - a concentration $(\mu \mathrm{g} / \mathrm{L}) . \mathrm{F}=2.43$ is the correction factor by acidification. $\mathrm{K}=10.48$ is the absorbance coefficient at $665 \mathrm{~nm}$ of wave length, $\mathrm{V}$ is the filtered volume in $\mathrm{L}$ and $\mathrm{v}$ is the extract volume of $8 \mathrm{~mL}$ [18].

\section{E. Statistical Analysis}

Each sample was taken by duplicate and T-Student was the selected probability distribution model to represent physicochemical quality and biological parameters of Libelula's Wetland. To understand limnologic and physicochemical interactions, relationships and the importance of all measured variables, the non-parametric Spearman correlation and principal component analysis PCA were calculated by PAST software of Oslo University.

\section{RESUlt ANALYSIS}

\section{A. Trophic State According to Carlson's T.S.I Index}

Following graph Fig. 1, shows behavior of Libelula's Wetland trophic state from May of 2017 to July of 2017 year, calculated by Carlson's Trophic State Index TSI, based on parameters called TSI Clearness, TSI Chlorophyll-a, and TSI Total Phosphorous. Intervals of different trophic state with low nutrient load (oligotrophic) to high nutrient load (eutrophic) are also presented there to help to understand how Libelula's Wetland must be considered [19]-[21].

These states unleash several consequences like a great biological spread with more nutrients but these aspects could lead more turbidity and low oxygen concentration in water that trigger the decline of ecosystem [13], [21], [22]. This is the case of Libelula's Wetland according to T.S.I index parameters where it ranks from eutrophic to hyper-eutrophic state (last state with the major quantities of nutrients), thus this ecosystem have high primary yield.

High values of TSI Clearness and TSI Chlorophyll-a show a hydric ecosystem have high turbidity due to suspended and dissolved solids which may be of chemical or biological origin, mainly the last one with a lot of photosynthetic species like phytoplankton and their constituent as proteins carbohydrates and more. Turbidity as excess of photosynthetic biomass which cover up wetland surface, results in a low reception of sunlight that interferes with aquatic photosynthetic metabolism and availability of oxygen concentration would become poor. For this, many aerobic species would die and their downgrade would bring more pollution and the show up of pathogenic and anaerobic biological species which is more difficult to treat [13], [22].

The higher trophic state related to total phosphorous shows that this element is dissolved in great amount in this Wetland and it does not limit the primary yield. Part of phosphate would precipitate with metals, other portion may be used by phytoplankton and plants to carry metabolism reactions that help to maintain life and promote the growth of photosynthetic living species and there is a high quantity which is dissolved in the water column of wetland [13], [19], [21], [23]-[25]. 
LIBELULA'S WETLAND TROPHIC STATE INDEX TS

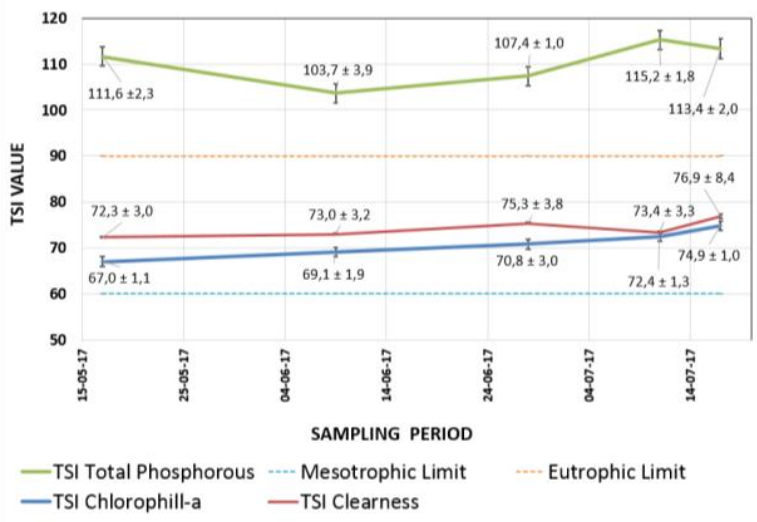

Fig. 1. Trophic state of Libelula's Wetland during May to July of 2017.

Natural cause of dissolved phosphorous content in the water column may be because of the liberation of phosphates from plants by organic and inorganic compounds downgrade or the phosphorous saturation inside living organism that lead to stop the macronutrient intake [13], [26], [27]. Other cause of high phosphorous content comes from domestic activities like cleaning with detergents and the release of human waste due to wrong connections. Also, industrial activities like tanneries and manufacture of goods as clothing, furniture and chemical products which may come from direct discharge or from connectivity with Tunjuelito River [9], [24], [25].

The consequence of this aspect is the vast growth of some photosynthetic species, increasing even more, the turbidity and promoting the dryness of Libelula's wetland. This last consequence is the worst of all due to the great loss of ecosystem services [11], [22].

Another observation is that trophic state was always increasing during sampling period. Although first dates (May and first half of June) where associated to rainy season, high nutrient quantity did not diminish as it happens in other urban wetlands in Bogotá [28]. This behavior may be explained by the movement of solids and nutrient in the water column because of the rain, causing more turbidity and that may easy the obtaining of nutrients by primary producers.

\section{B. Physicochemical Parameters Analysis}

One way to understand Libelula's Wetland behavior is the physical - chemical assessment presented in the following figures. Fig. 2 and Fig. 3 shows low oxygen concentration in water that increased at the end of rainy season, possibly because of mixing regime between rain and wetland water that included oxygen from atmosphere or as a product of photosynthesis from aquatic plants. This is a good characteristic, but water of wetland has a lot of organic and inorganic reduced material from natural (degradation of death matter) and human activities, that increased Chemical and Biochemical Oxygen Demand (COD and BOD parameter) in dry season [13], [29], [30]. The $\mathrm{pH}$ value kept constant during rainy season but went down during dry season (no effect by acid rain) [22]. Thus, another explanation is vegetal downgrade of plants covered by rain water that released humid acids that could reduce $\mathrm{pH}$ value in dry season.

Fig. 3 shows that clearness of Libelula's Wetland keep constant during time with a low decay in dry season because of the increase of suspended solids and phytoplankton suggested by the increase of chlorophyll-a concentration. Fig. 4 presents conductivity and concentration of ions' behavior which may be linked to growth and maintenance of living organisms. Ammonia and nitrite compounds were considered as the main nitrogen sources rather than nitrate compound because they are easily found in polluted water ecosystem with low oxygen concentration as in the case of Libelula's Wetland.

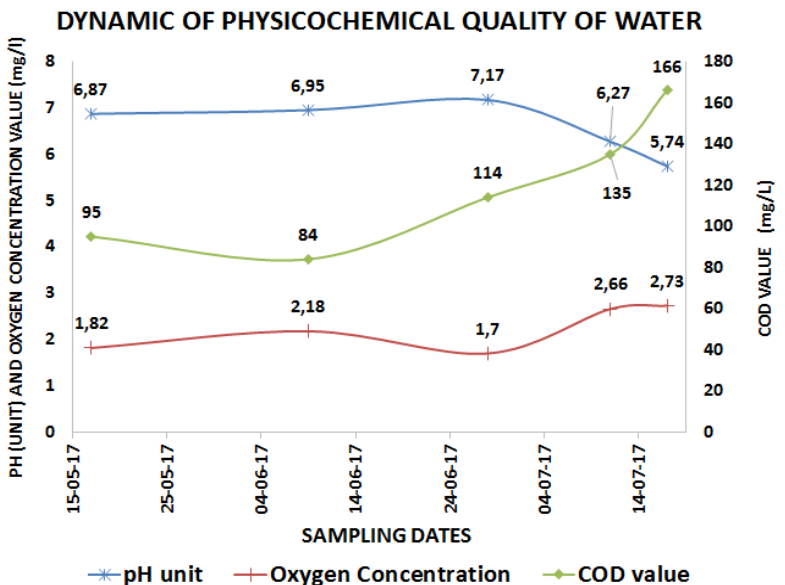

Fig. 2. Physicochemical behavior of Libelula's Wetland during May to July of 2017 (1).

Ammonia compound is a preferred nitrogen source for plants and phytoplankton than nitrite which may be a toxic compound for living organisms [13], [26], [27]. However, nitrite concentration decreased during most of the time of sampling period, while ammonia concentration increased during rainy season. This could be by nitrate (from rain) and nitrite reduction to ammonia by reductive bacteria.

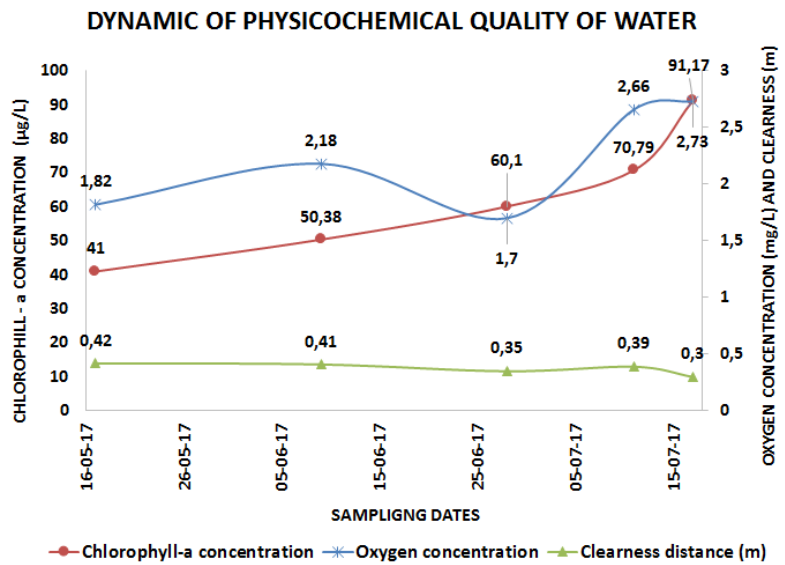

Fig. 3. Physicochemical behavior of Libelula's Wetland during May to July of 2017 (2).

Another reason is the human discharges enriched of urea and ammonia compounds. In dry season ammonia and nitrite concentrations have a similar behavior, maybe by photosynthetic organisms sorption or gas release to atmosphere [13].

Fig. 4 also shows diminish of phosphate compound during rainy season, possibly by dilution, precipitation or consumption by photosynthetic species. After this period, phosphate concentration rose possibly by liberation from sediments or organic matter from plant to continue with phosphorous circle. Iron and Chromium concentrations were also evaluated to see possible pollution from industrial 
sources like tanneries and metallurgical industries that would come with Tunjuelito River which crosses near Libelula's wetland and may connect between them.

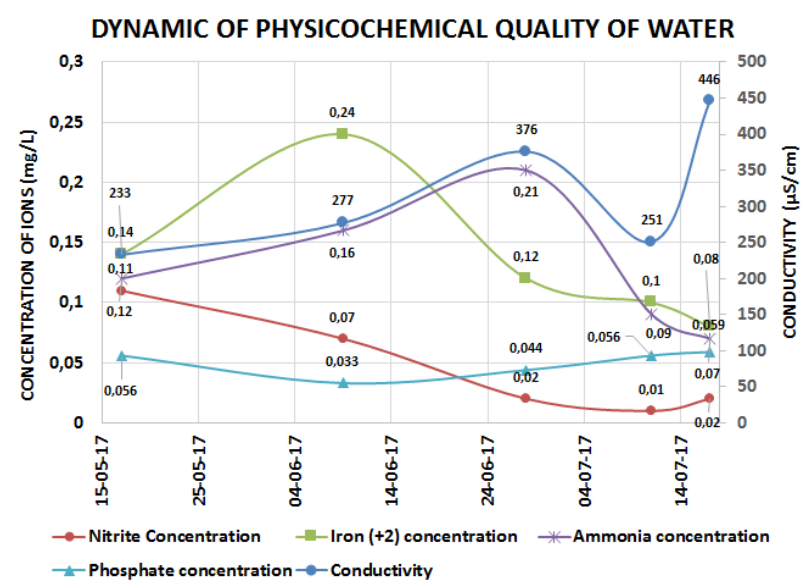

Fig. 4. Physicochemical behavior of Libelula's Wetland during May to July of 2017 (3).

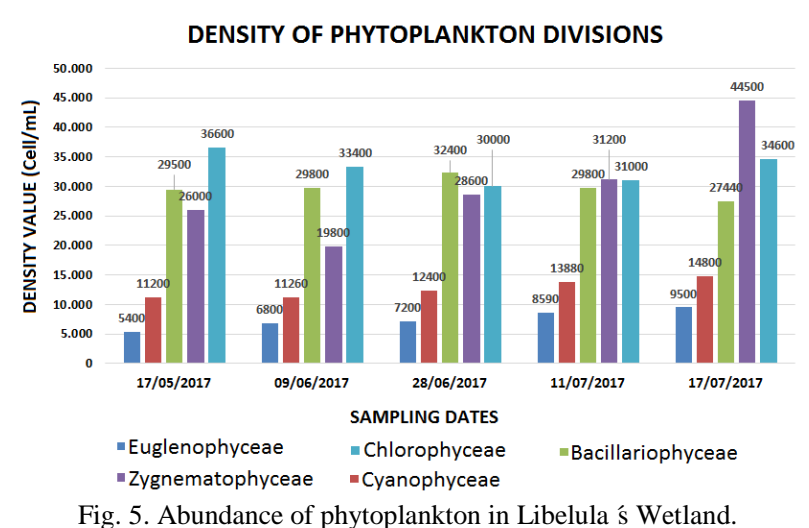

During sampling period chromium compounds were not found in water due to a change in tanneries processes before the execution of this project, but iron compounds were found in high concentration in rainy season and decreased at the beginning of dry season maybe by plant adsorption or precipitation with phosphates [13], [26], [27]. Conductivity behavior depends strongly on the presence of many ion compounds like sulfate, carbonate, chloride and their interaction. For this, conductivity do not behave exactly to an specific ion, however, the appearance of big amount of ions was represented by the high value of conductivity parameter [22].

\section{Biological Parameters Analysis}

Phytoplankton and Zooplankton were selected as the biological organisms to evaluate, because they are representative of primary and secondary yield. Thus, higher concentration of phytoplankton produces higher amount of zooplankton. Another reason to monitor phytoplankton concentration and composition is that these parameters may have high variability according to water quality [13], [26], [27], [31].

Fig. 5 shows phytoplankton abundance of Libelula's Wetland. Sampling allowed identifying that Chlorophyceae and Bacillariophyceae divisions had the bigger abundance during most of the sampling time, due to the speed of reproduction, nutrient wealth and great resistance to harsh conditions in water [15], [26], [32]-[34]. Last characteristic is evident in Bacillariophyceae species which have cell wall composed of silice, and some Chlorophyceae species can live inside a mucilaginous matrix. Those coverage give cell resistant to environment conditions [13], [35].

These divisions are considered as water pollution indicators and their highly presence in Libelula's water explain the altered state of this ecosystem, as TSI showed. This observation is agree with other researches of lentic ecosystems in Bogotá city [31], [36] and other places in the world [32], [34], [37].

Zygnematophyceae species also grew in polluted water. They are seasonal beings which prefer shallow water ecosystem and some of them grow well in aerated water with $\mathrm{pH}$ value from neutral to acid [13]. These conditions were reached at the end of rainy season as it was seen before. Fig. 5 presents the great increase of the Zygnematophyceae population at the end of the sampling period in comparison with other phytoplankton species.

Cyanophyceae division have the capability to live in stagnant water with high load of organic matter, phosphates and ammonia, and low oxygen concentration as in Libelula's Wetland [13], [38]. However the less quantity of Cyanophyceae division in comparison with Chlorophyceae and Bacillariophyceae division may be becausel last types of species prefer iluminated environments, meanwhile cyanobacteria can grow at the bottom of hydric ecosystems where light is limited, but sampling could not be done there. [15], [35], [39]-[41].

Also phytoplankton of eukariotic kingdom and zooplankton can use Cyanophyceae species as a food source, controlling cyanophyta quantity. Euglenophyceae species can grow with nutrient limitation but in presence of ammonia compound and organic matter. In Libelula's Wetland, these species were relevant [15], [33].

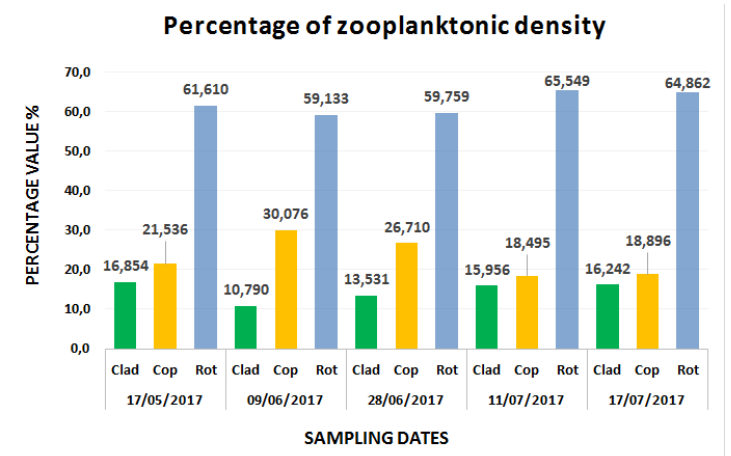

Fig. 6. Zooplankton abundance presented as density percentage during May to July of 2017.

Three type of Zooplanktonic organisms were evaluated: Cladocera, Copepoda, Rotifera because these biological subclasses and phylum are widely spread in many aquatic ecosystems and can adapt to several water conditions[13], [26]. Fig. 6 shows that subclass Rotifera had the highest density comparing to the other zooplankton organism. According to Colina (2013) [42], it was hoped to find this behavior, because Rotifera prevail in mesotrophic to eutrophic aqueous ecosystem where phosphorous concentration is unlimited while oxygen concentration may be variable. Rotifera's species eat phytoplankton, detritus and bacteria which are abundant in Libelula's Wetland. Copepoda is the second most plentiful type of zooplankton in 
Libelula's wetland. This type of animals grows in aquatic environments with different conditions, thus they can adapt easily everywhere. They use many types of phytoplankton and small animals like Rotifera and Cladocera as a food source and nutrient selection depends on the growth stage [13], [43]. The presence of Copepods in Libelula's Wetland is a matter of care because some species of Copepods can be intermediary innkeepers of several parasites which cause illness or death in, amphibian, birds, mammals and men.

Cladocera zooplankton uses chlorophytas as the main food sources. Due to the high amount of this phytoplankton, Cladocera was found in this ecosystem but the great amount of other compounds and low oxygen concentration could serve as growth restricting factor by nutrient excess and undesirable conditions [44].

\section{Estimation of Physical - Chemical and Biological Parameters Relationships by Spearman Correlation and PCA Analysis}

Relationships between Physical - chemical and biological parameters determine hydric ecosystems performance [13], [26], [27]. Spearman correlation and Principal Component Analysis (PCA) were the employed techniques to understand these interactions. For Spearman correlation, values near to unit value represent a strong relationship showed in Fig. 7 which shows parameters that had relationships over the $50 \%$ or 0.5 to $100 \%$ or 1.0 and Fig. 8 shows PCA, where the first two components explain the $95,33 \%$ of variance between parameters.

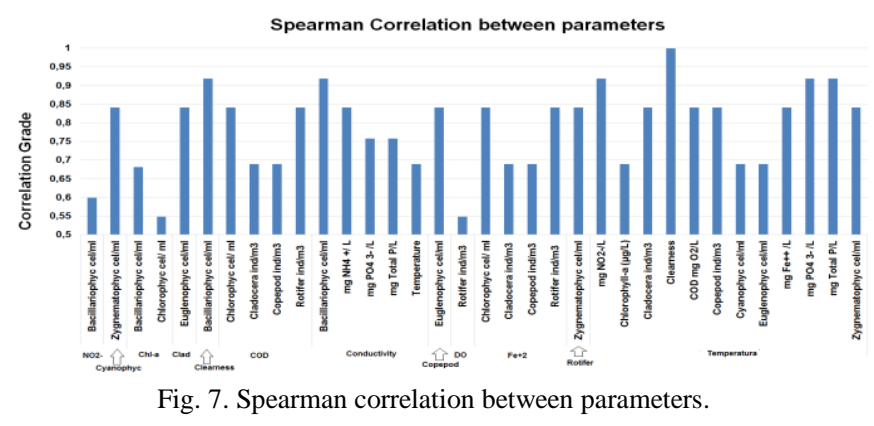

Spearman correlations show that temperature and conductivity had more relationship with ions like iron, ammonia, nitrite, and phosphates because the higher the amount of ions, the higher the conductivity value and the higher the temperature, the higher the ion activity, reaction rates and mobility, favoring the rising of turbidity (opposite of clearness), the rising of primary productivity (also seen with the increase of chlorophyll -a) and water eutrophication. As well as $\mathrm{pH}$ value depends on the amount of acid or basic compounds, it was hoped to have acid water behavior, because cations that are acid compounds were in greater quantity than anions [13], [22].

However, PCA shows that some ions appear to have an opposite relationship with first mentioned variables, because temperature can also promote the increase or decrease of living organism metabolism and consumption of dissolved nutrients, also temperature may ease or delay the release of ions from organic and inorganic matter due to downgrade, promoting the oxygen consumption at different rates (in the form of chemical demand). For this, relationship with temperature and other variables seem not to be linear. These changes would lead turbidity and first productivity (measured as chlorophyll - a) variation [22], [45].

Other explanation is the change of oxidation state as in the case of ammonia, iron +2 and nitrite. Nitrogen and iron could be in greater amounts but in different oxidation state, that might be not evaluated in this research but conductivity would still be high. This reason could also explain relationship between cations behavior and $\mathrm{pH}$ value. It was found that in water with oxygen and low $\mathrm{pH}$ values, iron could precipitate in its trivalent form. Thus, the lower the ph value, the lower the iron +2 . With respect to Ammonia quantity, it could be assimilated by plants and phytoplankton or converted in other nitrogen compounds releasing hydrogen ions and acidifying water.

Relationship between Phosphates and $\mathrm{pH}$ would be explained by the changes in the state of ion as was mentioned with iron ion but in dry season the decay of $\mathrm{pH}$ was possibly related with the release of humid acid from plants. With this release, phosphate would also be dissolved in aquatic media although a part of phosphate would precipitate with iron. Chorophyll-a is high because primary productivity is higher in basic water than in acid water and PCA shows the direct relationship with mix trophic phytoplankton maybe because chlorophyll-a is part of organic matter and release would lead more growth of those type of phytoplankton.

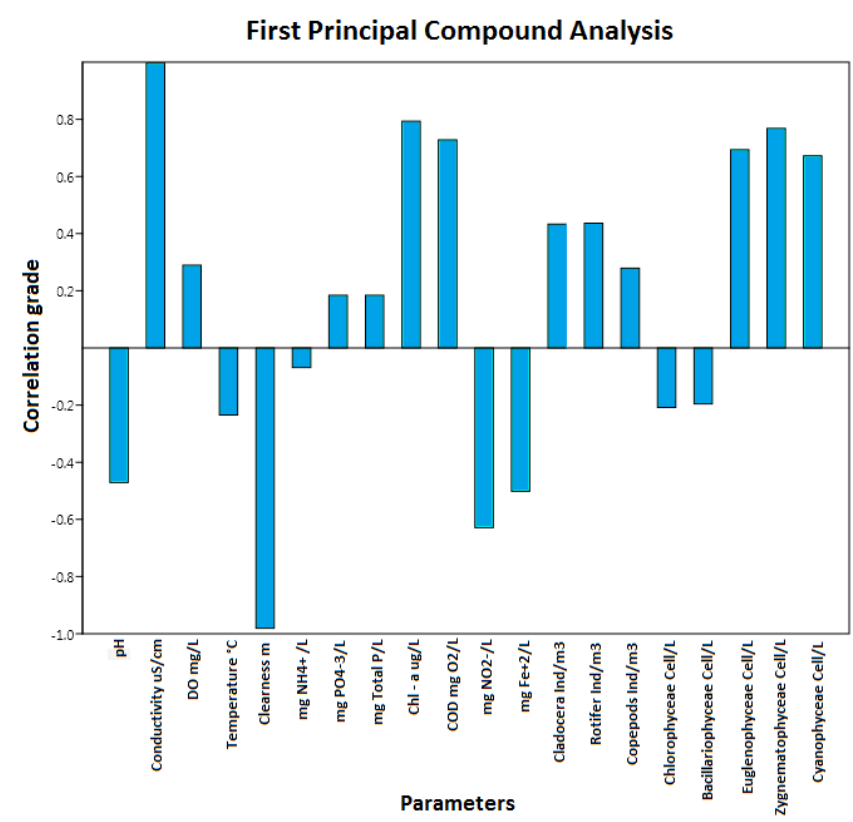

Fig. 8. First principal compound analysis obtained by PAST software.

This behavior is shown in Fig. 2 and Fig. 3 where phytoplankton biomass grew significantly until $\mathrm{pH}$ came down [13], but mixotrophic phytoplankton grew significantly. Due to the limitation of time in the sampling period, it was not possible to see if chorophyll - a, was lower at low $\mathrm{pH}$ vales.

PCA also showed that relationships of ions concentration with $\mathrm{pH}$ and conductivity are strong but not with temperature as Spearman correlation predicted [13], [45], [46], [47]. This poor relationship with temperature is also seen with biological parameters. Spearman correlation showed as an important relationship between temperature, phytoplankton and zooplankton which could grow in high load of organic matter, like Zygnematophyceae, Euglenophyceae, 
Cyanophyceae species, Copepod and cladocera species. In this research it was seen an opposite relationship between those parameters, due to higher temperature may promote stratification and low distribution of nutrients, limiting growth as Thomas said [48]. Other authors have found that these species can adapt themselves to different conditions [13], [15].

Fig. 8 also shows a direct and strong relationship between Euglenophyceae, Zygnematophyeceae and Cyanophyceae with COD, phosphates, total phosphorous, chlorophyll-a, oxygen concentration, and conductivity. These species are well spread in environments with high amount of organic and inorganic matter which also raised conductivity and dissolved phosphorous as it was seen in previous section. For example, in the case of Euglenophyceae species, they had a direct relationships with COD because their main food source are organic matter for the two- third which are facultative heterotrophic or phagotrophic organism for this reason, the increase of COD due to organic matter would lead to Euglenophyceae increase (Fig. 2 and Fig. 5).

Rotifers also had massive growth due to the food they find in dretritus and bacteria. Rotifera and Euglenophycea species had similar performance [13], [15], [35]. This direct relationship was not found with Chlorophyceae and Bacillariophyceae species, because they are light dependent and turbidity increase with the increase of COD.

The presence of chemical and biochemical compounds which lead to redox reactions increases the Chemical and Biochemical Oxygen Demand thus letting the decay of oxygen concentration [22], however PCA shows both COD and dissolved oxygen concentration have direct relationship. This is because the dissolution effect of oxygen from atmosphere during rainy season and the arriving of organic and inorganic matter to Wetland from human sources or partially death of aquatic vegetation at the same time. Zooplankton was also directly related to these phytoplankton species because, these last ones are nutrient source of zooplankton and Spearman correlation shows the preference of zooplankton grazing. Thus the higher, the amount of phytoplankton, the higher the amount of zooplankton [42]. All these causes are indirect related to temperature.

Also Fig. 8, an opposite relationship with nitrogen compounds and iron+2 with Euglenophyceae, Zygnematophyeceae and Cyanophyceae species. Relationship with ammonia compound and phytoplankton is not strong despite of the inverse effect. However the relationship is stronger with nitrite compound. Then, the lower the nitrite concentration, the higher, the amount of mix trophic phytoplankton species. This is because nitrite compound could be toxic for these organism. In the case of Bacillariophycea and Chlorophyceae, they seem to be more resistant to nitrite compound and can assimilate it as nitrogen source. In this way, last type of phytoplankton are related to nitrogen compounds directly [49], [50].

The opposite effect with iron, phytoplankton and copepods may be explained by the high amount of iron which leads to a toxic environment. Also in this case, Chlorophyceae and Bacillariophyceae species seem to be more tolerant and grow even though the high amount of iron in Libelula's wetland [51], [52].

Bacillariophyceae species showed a strong relationship with conductivity and clearness, in agreement with Spearman Correlation and PCA. According to Diaz \& others, the correspondence analysis between conductivity and Bacillariophyceae showed a directly proportional behavior when conductivity presented values fewer than 350 us / cm; from there, behavior between conductivity and Bacillariophyceae species was inversely proportional.[40] These behaviors may be explained because Bacillariophyceae species need nutrient and micronutrient to survive in Libelula's Wetland but in great concentration of ions, nutrient act as growth limiting factor due to toxicity effect by nutrient excess. Bacillariophyceae species live well in illuminated environments. This is the reason of the direct relationship between Bacillariophyceae species and clearness because sun light gets inside water easily. In this study it was seen that Bacillariophyceae species decreased when clearness also decreased [45], [53].

According to PCA, Copepods species had the least relationship with COD this is because this type of animal do not always depend directly of organic matter as some phytoplankton and rotifer species do. These species are Copepods' food, but Copepods could also eat photosynthetic phytoplankton which only depends of photosynthesis, for this Copepods could grow in a environment with high or low COD. Although the lower relationship show that Copepods could prefer ecosystems with a certainly COD value to have enough food but copepods species has energy resource which uses mainly when phytoplankton is few as Ikeda explained [54].

The last relationship between physical chemical parameters and biological parameters is Chlorophyceae and Bacillariophyceae species with Chlorophyll - a. These phytoplankton species produce this type of Chlorophyll - a. but at the end of rainy season other phytoplankton species would produce more [35].

\section{CONCLUSIONS}

The correlation with physicochemical and biological parameters allow to understand Libelula's Wetland behavior to give an appropriate ecological and economical value to these type of water resources. Although the interactions of many of variables that were happening at the same time was not an easy work, and comparison between Libelula's performance was done with other type of water sources from different part of the world which have different ecosystem conditions. Thus, given explanation in this research might differ from those studies. The relationships obtained with PCA and Spearman correlation were conflicting somehow. This way it is recommended to explore another statistical and nonlinear techniques which may allow to obtain more consisten results with wetland's behavior.

\section{REFERENCES}

[1] R. De Groot, M. Stuip, M. Finlayson, and N. Davidson, "Valoración de humedales. Lineamientos para valorar los beneficios derivados de los servicios de los ecosistemas de humedales. Informe Técnico de Ramsar núm. 3 Núm. 27 de la serie de publicaciones técnicas del CBD," Suiza and Montreal: Secretaría de la Convención de Ramsar and Secretaría del Convenio sobre la Diversidad Biológica, 2007.

[2] R. Costanza et al., "The value of the world' s ecosystem services and natural capital," Nature, vol. 387, May, pp. 253-260, 1997. 
[3] Secretaría de la Convención de Ramsar, "Uso racional de los humedales: Conceptos y enfoques para el uso racional de los humedales," Manuales Ramsar, p. 64, 2010.

[4] Secretaría de la Convención de Ramsar, "Humedales: ¿Por qué cuidarlos ?" Fichas Informativas Ramsar, pp. 1-2, 2015.

[5] R. C. Gardner et al., "State of the world's Wetlands and their services to people: A compilation of recent analyses," 2015.

[6] Encolombia. (2017). Humedales de Bogotá: Evolución histórica. [Online].

Available: https://encolombia.com/medio-ambiente/humedales/bogotah/hhb/

[7] S. J. D. de la A. M. de B. D.C, Acuerdo 19, 1994

[8] S. J. D. de la A. M. de B. D.C., Acuerdo 487, 2011

[9] D. Hammen et al., Protocolo De Recuperación Y Rehabilitación, 2008

[10] M. Kravcik, J. Pokorný, J. Kohutiar, M. Kovác, and E. Tóth, "Water for the recovery of the climate - A new water paradigm," pp. 1-94, 2008.

[11] Secretaría de la Convención de Ramsar, "El cuidado de los humedales: Una respuesta al cambio climático," 2010.

[12] G. S. Cumming et al., "An exploratory framework for the empirical measurement of resilience," Ecosystems, vol. 8, no. 8, pp. 975-987, 2005.

[13] G. Roldan and J. Ramírez, Fundamentos de Limnología Neotropical, Medellín: Universidad de Antioquia, 2008.

[14] American Public Health Association, American Water Works Association, and Water Environmental Federation, "Standard methods for the examination of water and wastewater, 20th edition," p. 2327, 1998.

[15] E. G. Bellinger and D. C. Sigee, Freshwater Algae, 2010.

[16] Intergovernmental Oceanographic Commission, Microscopic and Molecular Methods for Quantitative Phytoplankton Analisys, Paris: United Nations Educational, Scientific and Cultural Organization, 2010.

[17] M. Menéndez, G. Pistone, and S. Castro, "Determinación de Clorofila a, b y C1 'C2 y feopigmentos de Clorofila a (feofitina a) encontrados en fitoplancton de agua dulce y marina. Método espectrofotométrico de extracción con acetona.," 2009.

[18] C. R. Rivera, Á. A. Zapata, G. Pinilla, J. Donato, B. Chaparro, and P. Jiménez, "Comparación de la estimación de la clorofila - A mediante los métodos espectrofotométricos y fluorométricos," Acta Biológica Colomb., vol. 10, no. 2, pp. 95-103, 2005

[19] D. M. Franco, J. Q. Manzano, and A. L. Cuevas, "Metodos para identificar, diagnosticar y evaluar el grado de eutrofia," ContactoS, vol. 78, pp. 25-33, 2010.

[20] M. L. López and S. Madroñero, "Estado trófico de un lago tropical de alta montaña: Caso Laguna de la Cocha.," Cienc. e Ing. Neogranadina. vol. 25 , no. 2 , pp. 21-42, 2015.

[21] G. L. Vásquez et al., "Metodología para determinar niveles de Eutrofización en ecosistemas acuáticos," Rev. la Asoc. Colomb. Ciencias Biológicas, vol. 1, no. 24, pp. 112-128, 2012.

[22] C. Sawyer, P. McCarty, and G. Parkin, "Chemistry for environmenta engineering and science," p. 752, 2003.

[23] N. Ab, W. Ashwani, J. A. D, and W. Rajni, "Pollution effects \& control trophic status of bhoj wetland on the basis of some chemica characteristics," vol. 2, no. 1, pp. 2-4, 2014.

[24] G. F. Lee, G. F. Lee, W. Rast, W. Rast, R. A. Jones, and R. A. Jones, "Eutrophication of water bodies: Insights for an age-old problem,' Environ. Sci. Technol, vol. 12, no. August, pp. 900-908, 1978.

[25] V. H. Smith, "Eutrophication review," Enciclopedia of Inland Waters, vol. 3, Oxford: Elsevier, 2009, pp. 1159-1166.

[26] R. Margalef, Limnología, Barcelona: Ediciones Omega, 1983

[27] G. R. Wetzel, Limnology, New York: Saunders College Publishing, 1983.

[28] J. Beltrán and J. Rangel, "ModelacióN del estado trÓFICO de humedal de jaboque , bogotÁ D . C ., colombia modeling the trophic state of Wetland Jaboque , Bogotá D . C ., Colombia,” Acta Biológica Colomb., vol. 18, no. 1, pp. 149-164, 2013.

[29] P. Doran, Bioprocess Engineering Principles, vol. 9, no. 1. 1996.

[30] R. E. Treybal, Operaciones de Transferencia de Masa, McGraw Hill, 1984.

[31] J. E. B. Vargas, "Modelación de la producción primaria fitoplanctónica en el humedal Jaboque, Bogotá D.C.," Rev. Tecnura, vol. 20, no. 47, p. 85, 2016.

[32] Y. Z. Domitrovic, V. M. Asselborn, and S. L. Casco, "Variaciones espaciales y temporales del fitoplancton en un lago subtropical de Argentina," Rev. Bras. Biol., vol. 58, no. 3, pp. 359-382, 1998.

[33] B. P. Barrios, "Variaciones estacionales y verticales de la composición, abundancia y diversidad de la comunidad fitoplanctonica del embalse del Neusa,” Bogotá: Universidad Jorge Tadeo Lozano, 2005.
[34] L. León and G. Chalar, "Abundancia y diversidad del fitoplancton en e Embalse de Salto Grande (Argentina - Uruguay). Ciclo estacional y distribución espacial," Limnetica, vol. 22, no. 1-2, pp. 103-113, 2003.

[35] L. Barsanti and P. Gualtieri, Algae. Anatomy, Biochemistry and Biotechnology, Boca Ratón: Taylor and Francis, 2006.

[36] L. Rodriguez, "Determinación Del Estado Trófico De Tres Ecosistemas Lénticos De La Sabana De Bogotá Con Base Al Fitoplancton, En Dos Periodos Climáticos Contrastantes," vol. 1, Bogotá: Universidad Militar Nueva Granada, 2012, pp. 1-116.

[37] L. F. Cala, "Proposta de manutenção e preservação do lago de campo grande - Lisboa - Portugal, em relação com a qualidade da água," Universidade de Lisboa, 2011

[38] H. W. Paerl and J. Huisman, "Climate change: A catalyst for global expansion of harmful cyanobacterial blooms," Environ. Microbiol. Rep., vol. 1, no. 1, pp. 27-37, 2009

[39] M. A. Rodrigo et al., "Assessing the effect of emergent vegetation in a surface-flow constructed wetland on eutrophication reversion and biodiversity enhancement," Ecol. Eng., vol. 113, no. July 2017, pp. 74 87, 2018.

[40] C. Díaz-Quirós and C. A. Rivera-Rondón, "Diatomeas De Pequeños Ríos Andinos Y Su Utilización Como Indicadoras De Condiciones Ambientales," Caldasia, vol. 26, no. 2, pp. 381-394, 2004.

[41] E. Céspedes-Vargas, G. Umaña-Villalobos, and A. M. Silva-Benavides, "Tolerancia de diez especies de diatomeas (Bacillariophyceae) a los factores físico-químicos del agua en el Río Sarapiquí, Costa Rica," Rev. Biol. Trop., vol. 64, no. 1, pp. 105-115, 2016.

[42] M. Colina, "Aproximación funcional al pastoreo del zooplancton sobre Grupos Funcionales Basados en Morfología de fitoplancton,” 2013.

[43] J. L. Gómez-Márquez, B. Peña-Mendoza, J. L. Guzmán-Santiago, and V. Gallardo-Pineda, "Composición, abundancia del zooplancton y calidad de agua en un microreservorio en el estado de morelos," Hidrobiologica, vol. 23, no. 2, pp. 227-240, 2013.

[44] L. Forró, N. M. Korovchinsky, A. A. Kotov, and A. Petrusek, "Globa diversity of cladocerans (Cladocera; Crustacea) in freshwater,' Hydrobiologia, vol. 595, no. 1, pp. 177-184, 2008.

[45] M. Shuler and F. Kargi, "How cells grow," Bioprocess Engineering. Basic Concepts., New Jersey: Prentice Hall, 1992, pp. 148-178.

[46] J. Raven and R. Geider, "Temperature and algal growth," New Phytol., p. 20, 1988.

[47] C. Ledesma, M. Bonansea, C. M. Rodriguez, and A. R. S. Delgado, "Determinación de indicadores de eutrofización en el embalse Río Tercero, Córdoba (Argentina),” Rev. Cienc. Agron., vol. 44, no. 3, pp 419-425, 2013.

[48] M. Thomas, "The effect of temperature on the ecology evolution and biographic of phytoplankton," Michigan State University, 2013.

[49] V. Almanza et al., "Floraciones de fitoplancton y variación de la estructura comunitaria fitoplanctonica en tres lagos someros eutróficos de Chile central.," Botanica, p. 14, 2016

[50] J. T. Kim and M. B. Sung, "The relationship of green euglenoids to environmental variables on Jeonjucheon, Korea," Korean J. Limnol. vol. 2, p. 8, 2001.

[51] H. Schoffman, H. Lis, Y. Shaked, and N. Keren, "Iron - Nutrien Interactions within phytoplankton," Front. Plant Sci., vol. 7, 2016.

[52] X. Chen, S. Baines, and N. Fisher, "Can copepods be limited by the iron content of their food?" Limnol. Oceanogr., vol. 2, p. 9, 2011.

[53] J. Lopez and A. Mendez, "Evaluación de la concentración de los grupos de fitoplancton: Diatomeas, Cianofitas, Clorofitas y Dinoflagelados, y su relación con los parámetros fisicoquímicos, en las aguas del Río Estero Real, periodo Junio - Noviembre 2013,' Universidad Nacional Autónoma de Nicaragua, 2014.

[54] T. Ikeda, "Changes in respiration rate and in composition of organic matter in Calanus Cristatus (Crustacea Copepoda) under starvation," Bull. Fac. Fish. Hokkaido Univ., pp. 280-298, 1971.

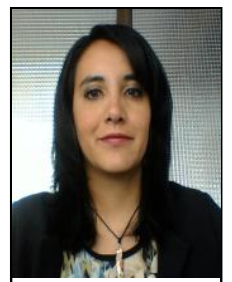

Liliana Ardila Forero is a chemical engineering of National University of Colombia - South America with a master degree on environmental engineering, focused on water resources and treatment with biochemical processes with a praiseworthy thesis, from the same university. She has worked on the study on natural water resources in Colombia and their physicochemical and biological parameters. She has been working as a teacher for almost a decade teaching courses related to chemical, environmental engineering in differente national universities. Msc. Eng. Ardila is working as a teacher at ECCI University for the Environmental Engineering career. Nowadays She is leading a research group on the field of Limnology and student's projects are related from the evaluation of trophic state of wetlands and algae photo bioreactors design to study the pollutant bioindicator capability on water. 
Steven Ricardo Mora Gonzalez is an environmenta engineer of ECCI University, Bogotá, Colombia. With knowledge in the use of "GIS" tools through the processing, evaluation and interpretation of geospatial information derived from environmental monitoring programs, satellite images, UAV technologies an other sources of information to limnological evaluation of lentic ecosystems, environmental impact assessment (EIA), environmental management plans (PMA), assessment of ecosystem services, and management of natural risks especially floods and multicriteria analysis.

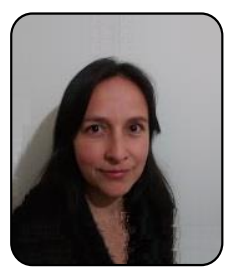

Ruth Flórez is a biologist of Industrial University of Santander - Colombia, with master's degree in environmental science at Buenos Aires University Argentina. She has focused her research field in Limnology and environmental toxicology. She is an associated Professor of ECCI University and leads water ecosystem assessment in Colombian Highland tropical ecosystems research. 